\title{
UCRL-JRNL-229831
}

LAW RENCE LIVERMORE N A T IO N A L LABORATORY
Effect of Electrode Composition and Microstructure on Impedancemetric Nitric Oxide Sensors based on YSZ Electrolyte

L. Y. Woo, L. P. Martin, R. S. Glass, W. Wang, S. Jung, R. J. Gorte, E. P. Murray, R. F. Novak, J. H. Visser

April 10, 2007

Journal of the Electrochemical Society 
This document was prepared as an account of work sponsored by an agency of the United States Government. Neither the United States Government nor the University of California nor any of their employees, makes any warranty, express or implied, or assumes any legal liability or responsibility for the accuracy, completeness, or usefulness of any information, apparatus, product, or process disclosed, or represents that its use would not infringe privately owned rights. Reference herein to any specific commercial product, process, or service by trade name, trademark, manufacturer, or otherwise, does not necessarily constitute or imply its endorsement, recommendation, or favoring by the United States Government or the University of California. The views and opinions of authors expressed herein do not necessarily state or reflect those of the United States Government or the University of California, and shall not be used for advertising or product endorsement purposes. 


\section{Effect of Electrode Composition and Microstructure on Impedancemetric Nitric Oxide Sensors based on YSZ Electrolyte}

Leta Y. Woo ${ }^{a, b}$, L. Peter Martin ${ }^{a}$, Robert S. Glass ${ }^{a}$, Wensheng Wang ${ }^{b}$, Sukwon Jung ${ }^{b}$, Raymond J. Gorte ${ }^{b}$, Erica P. Murray ${ }^{c}$, Robert F. Novak ${ }^{c}$, and Jaco H. Visser ${ }^{c}$

${ }^{a}$ Lawrence Livermore National Laboratory, Livermore, California 94551, $U S A$

${ }^{b}$ Department of Chemical and Biomolecular Engineering, University of Pennsylvania, Philadelphia, Pennsylvania 19104, USA

${ }^{c}$ Ford Motor Company, Dearborn, Michigan 48121, USA 


\section{Abstract}

The role of metal ( $\mathrm{Au}, \mathrm{Pt}$, and $\mathrm{Ag}$ ) electrodes in YSZ electrolyte-based impedancemetric nitric oxide (NO) sensors is investigated using impedance spectroscopy and equivalent circuit analysis. The test cell consists of a rectangular block of porous YSZ with two metal wire loop electrodes, both exposed to the same atmosphere. Of the electrode materials, only Au was sensitive to changes in NO concentration. The impedance behavior of porous Au electrodes in a slightly different configuration was compared with dense $\mathrm{Au}$ electrodes and was also insensitive to NO. Ag showed no sensitivity to either $\mathrm{O}_{2}$ or $\mathrm{NO}$, and the measured impedances occurred at frequencies $>$ $10 \mathrm{kHz}$, which are typically associated with ionic conduction in YSZ. Pt and porous $\mathrm{Au}$ showed sensitivity to $\mathrm{O}_{2}$, which was quantified using power-law exponents that suggest electrochemical rate-determining mechanisms occurring at the triple phase boundary. The behavior of the dense Au suggests different rate-determining processes (e.g., diffusion or adsorption) for the $\mathrm{O}_{2}$ reaction. Although the exact mechanism is not determined, the composition and microstructure of the metal electrode seem to alter the rate-limiting step of the interfering $\mathrm{O}_{2}$ reaction. Impedance behavior of the $\mathrm{O}_{2}$ reaction that is limited by processes occurring away from the triple phase boundary may be crucial for impedancemetric NO sensing. 


\section{Introduction}

There has been considerable effort to develop high-temperature gas sensors for combustion-related emissions, and a fast, reliable $\mathrm{NO}_{x}$ sensor is required to comply with governmental regulations for emission limits. ${ }^{1-5}$ Ceramicbased solid-state sensors are particularly well suited for in-situ operation in harsh automotive environments. Yttria-stabilized zirconia (YSZ) has been shown to be a good candidate electrolyte material. ${ }^{1-5}$ Development of YSZbased potentiometric and amperometric $\mathrm{NO}_{x}$ sensors has typically targeted different types of metal-oxide electrodes to optimize the response. ${ }^{6-9}$ However, stability has proven to be a problem for the long lifetimes required (up to 10 years), where operation at constant current or voltage may induce

aging effects that lead to both morphological and compositional changes. ${ }^{10}$ Complicated device structures affecting cost and miniaturization are also a problem for amperometric $\mathrm{NO}_{x}$ sensing, which may require a separate $\mathrm{O}_{2}$ removal pumping cell, and for potentiometric sensing, which may require a separate reference gas.

Solid-state impedance spectroscopy measures electrochemical cell properties over a range of frequencies, typically from sub-Hertz to mega-Hertz. ${ }^{11}$ The frequency-dependent properties can be used to identify individual electrochemical components if they have significantly different time constants (e.g., grain boundaries and grain cores in polycrystalline materials), in which case they can be separated for individual analysis. The electrode impedance, 
primarily associated with the behavior of the electrode/electrolyte interface, dominates the low-frequency regime, typically less than $1 \mathrm{kHz}$.

YSZ-based impedancemetric sensors have been reported for sensing water vapor, hydrocarbons, $\mathrm{CO}$, and $\mathrm{NO}_{x} \cdot{ }^{12-15}$ A typically small-amplitude alternating signal is applied, and the sensor signal is measured at a specified frequency. Previous impedancemetric techniques have used the modulus (or magnitude) at low frequencies $(\leq 1 \mathrm{~Hz})$ as the sensing signal and attribute the measured response to interfacial phenomena. ${ }^{12-14}$ More recent work has also investigated using phase angle as the sensing signal at higher frequencies $(10 \mathrm{~Hz}) .{ }^{15,16}$ The higher frequency measurements would potentially allow for reduced sampling times during sensor operation.

Another potential advantage of impedancemetric $\mathrm{NO}_{x}$ sensing is the similarity in response to $\mathrm{NO}$ and $\mathrm{NO}_{2}$ (i.e., total- $\mathrm{NO}_{x}$ sensing). ${ }^{12,13,15,16}$ Potentiometric $\mathrm{NO}_{x}$ sensors typically show higher sensitivity to $\mathrm{NO}_{2}$ than $\mathrm{NO}$, and responses that are opposite in sign. However, NO is more stable than $\mathrm{NO}_{2}$ at temperatures $>600^{\circ} \mathrm{C}$, and thermodynamic calculations predict $\sim$ 90\% NO, balance $\mathrm{NO}_{2} \cdot{ }^{17}$ Since automotive exhaust sensors will probably be required to operate at temperatures $>600^{\circ} \mathrm{C}$, NO is the dominant component in thermodynamic equilibrium and the target $\mathrm{NO}_{x}$ species. Also, the use of upstream catalysts could further promote the conversion of $\mathrm{NO}_{x}$ species to NO. Therefore, the focus of the current work is to investigate the response to NO. 
Mitigating the effect of interfering gases (e.g., $\mathrm{O}_{2}$, water vapor, hydrocarbons, etc.) is also necessary for sensor operation. For application in automotive exhaust, strategies are being developed to account for hydrocarbons and other gases. For impedancemetric $\mathrm{NO}_{x}$ sensors, previous work has demonstrated that the cross-sensitivity to $\mathrm{O}_{2}$ may be accounted for by comparing measurements at multiple frequencies. ${ }^{15}$ A preliminary crosssensitivity study in conjunction with automotive dynamometer testing of an impedancemetric YSZ-based sensor has been conducted and will be published in a separate study.

Recent work by the authors investigated the impedance response of a symmetric $\mathrm{Au} / \mathrm{YSZ} / \mathrm{Au}$ cell to $\mathrm{O}_{2}$ and $\mathrm{NO}_{x} \cdot{ }^{16}$ The cell had a symmetric, in-plane geometry consisting of a dense YSZ electrolyte and two planar $\mathrm{Au}$ plates, with a porous YSZ layer separating the $\mathrm{Au}$ and dense YSZ. Both electrodes were co-located on the same side of the electrolyte and exposed to the same gaseous environment (i.e., no reference gas). To further understand the impedancemetric $\mathrm{NO}_{x}$ sensing mechanism, the current work focuses on the role of the dense Au electrode. Symmetric samples consisting of a porous rectangular block of YSZ with two metal wire loop electrodes are characterized using impedance measurements with the data then fit with an equivalent circuit. The impedance response of $\mathrm{Au}$ electrodes in different gas concentrations is compared with the impedance response of $\mathrm{Ag}$ and $\mathrm{Pt}$ electrodes. The role of microstructure is also investigated by comparing the 
impedance response of dense and porous $\mathrm{Au}$.

\section{Experimental}

Rectangular blocks $(17 \mathrm{~mm} \times 5 \mathrm{~mm} \times 3 \mathrm{~mm})$ of porous yttria-stabilized zirconia (YSZ) were fabricated using a slurry of YSZ powder (Tosoh Corp., $8 \mathrm{~mol} \% \mathrm{Y}_{2} \mathrm{O}_{3}$-doped $\mathrm{ZrO}_{2}, 0.2 \mu \mathrm{m}$ particle size), mixed with distilled water, dispersant (Duramax 3005, Rohm \& Haas), binders (HA12 and B1000, Rohm \& Haas), and graphite pore formers (GE, AlfaAeser, 325 mesh, con-

ductivity grade). ${ }^{18-20}$ Samples were sintered in air at $1550^{\circ} \mathrm{C}$ and resulted in 65 to $70 \%$ porosity, as determined by water uptake measurements, and fairly uniform pore sizes between 1 to $2 \mu \mathrm{m}$, as shown in the SEM picture in Fig. 1a.

Symmetric electrodes consisted of two tightly wrapped $\mathrm{Au}, \mathrm{Ag}$, or $\mathrm{Pt}$ wire loops wound around the long axis of the rectangular block, as shown in Fig. 2a. The separation distance between the wire loops varied from 2 to $7 \mathrm{~mm}$. Additional YSZ slurry was applied on the wires and fired in air at $1000^{\circ} \mathrm{C}$ for $2 \mathrm{~h}$. Figure $1 \mathrm{~b}$ shows an SEM picture of the fired slurry.

To elucidate the role of the Au electrode, another electrode configuration was also investigated using symmetrical thin Au plates $(6 \mathrm{~mm} \times 6 \mathrm{~mm})$ pressed against either side of the porous YSZ block, as shown in Fig. 2b, with and without a layer of Au paste (ESL 8880-G) between the Au plate and porous YSZ. The Au paste was fired in air at $850^{\circ} \mathrm{C}$ for $1 \mathrm{~h}$ to produce a 
porous Au interlayer. External leads for electrical measurements were made using Au metal contacts applied against the thin Au plates.

Gas sensing experiments were performed in a quartz tube $(16.8 \mathrm{~mm}$ I.D.) placed inside a tube furnace with both electrodes exposed to the same environment. The gas flow rate was maintained at $100 \mathrm{ml} / \mathrm{min}$ with composition controlled by mixing air, $\mathrm{N}_{2}$, and 1000 ppm NO using a standard gas handling system equipped with thermal mass flow controllers.

Electrochemical measurements were performed using a Solartron Analytical SI 1260 Impedance/gain-phase analyzer with the Solartron Analytical SI 1287 electrochemical interface. Computer-controlled data acquisition used the commercially available ZPlot and CorrWare software (Scribner Associates, Inc.). Impedance spectra were obtained using an excitation voltage of $50 \mathrm{mV}$ over the frequency range $1 \mathrm{MHz}$ to $1 \mathrm{~Hz}$ at 10 steps per frequency decade. The excitation voltage was chosen based on current-voltage (IV) measurements performed over the potential range -100 to $100 \mathrm{mV}$, which always produced linear (ohmic) IV behavior. Impedance spectra were analyzed using Boukamp's EQUIVCRT.COM software. ${ }^{21}$ 


\section{Results and Discussion}

\section{Impedancemetric sensing behavior}

For gas concentrations containing both $\mathrm{O}_{2}$ and $\mathrm{NO}_{x}$, the following redox reactions may occur:

$$
\begin{gathered}
\frac{1}{2} \mathrm{O}_{2}+2 e^{-} \rightleftharpoons \mathrm{O}^{2-} \\
\mathrm{NO}_{2}+2 e^{-} \rightleftharpoons \mathrm{NO}+\mathrm{O}^{2-}
\end{gathered}
$$

Previous work by the authors proposed parallel contributions from the $\mathrm{O}_{2}$

and $\mathrm{NO}_{x}$ reactions to the measured impedance in the $\mathrm{Au} / \mathrm{YSZ} / \mathrm{Au}$ system. ${ }^{16}$ For gas mixtures containing $100 \mathrm{ppm}$ or less of $\mathrm{NO}_{x}$ and $2-18.9 \% \mathrm{O}_{2}$, the contribution of the $\mathrm{O}_{2}$ reaction to the measured impedance is much greater than the $\mathrm{NO}_{x}$ reaction due to the much larger $\mathrm{O}_{2}$ concentration. The ratio between the two contributions then determines whether changes in the smaller contribution of the $\mathrm{NO}_{x}$ reaction will allow $\mathrm{NO}_{x}$ species to be detected. If the contribution of the $\mathrm{O}_{2}$ reaction to the measured impedance is much larger than the $\mathrm{NO}_{x}$ reaction, changes in the $\mathrm{NO}_{x}$ concentration would not affect the total measured impedance. Therefore, the $\mathrm{O}_{2}$ reaction may play a crucial role in determining $\mathrm{NO}_{x}$ sensitivity.

Electrochemical redox reactions involve a complex series of steps (e.g., adsorption of gas species, transport along surfaces, electron transfer, diffusion of products away from reaction sites, etc.), and numerous studies, especially in the area of solid oxide fuel cells, have sought to determine ratelimiting mechanisms in an effort to improve fuel cell performance. ${ }^{22-27}$ In 
the current work, changes in the rate-limiting mechanism for the $\mathrm{O}_{2}$ reaction, by altering the electrode composition or microstructure, are shown to affect the ability to detect NO. This is a direct consequence of the parallel contributions of the $\mathrm{O}_{2}$ and $\mathrm{NO}_{x}$ reactions to the measured impedance, where the contribution of the $\mathrm{O}_{2}$ reaction affects the relative influence of the $\mathrm{NO}_{x}$ reaction.

A commonly used method to investigate the rate-limiting step is measuring the electrode resistance $\left(R_{e l}\right)$ over a range of $\mathrm{O}_{2}$ partial pressures $\left(\mathrm{P}_{\mathrm{O}_{2}}\right)$ :

$$
R_{e l} \propto \mathrm{P}_{O_{2}}^{\beta}
$$

where the value of $\beta$ is used to characterize the type of species involved and the corresponding elementary reaction step that could be rate-limiting.

Figure 3 shows the Nyquist behavior of the porous YSZ block with wrapped $\mathrm{Au}$ wires $(\mathrm{Au} / \mathrm{YSZ} / \mathrm{Au})$ at $650^{\circ} \mathrm{C}$ in $10.5 \% \mathrm{O}_{2}, 10.5 \% \mathrm{O}_{2}+100 \mathrm{ppm}$ NO, and $18.9 \% \mathrm{O}_{2}$. The separation distance between the wire loops, which varied from 2 to $7 \mathrm{~mm}$, did not influence the measured impedance. In Fig. 3, numbers corresponding to darkened points represent log of frequency in Hz. Two frequency ranges of impedance behavior are clearly evident, separated by a distinct cusp. The addition of either $\mathrm{NO}$ or increasing $\mathrm{O}_{2}$ concentration causes similar changes in the low-frequency behavior $(<1 \mathrm{kHz})$, while the high-frequency behavior $(>1 \mathrm{kHz})$ remains unaffected.

The change in concentration for NO (0 to $100 \mathrm{ppm})$ is about three or- 
ders of magnitude smaller than the change in $\mathrm{O}_{2}$ concentration from $10.5 \%$ to $18.9 \%$, but both result in similar reductions in impedance. Therefore, the changes in the low-frequency behavior, associated with the electrode and electrode/electrolyte interface, are much more sensitive to $\mathrm{NO}$ than $\mathrm{O}_{2}$. Previous work by the authors has shown qualitatively similar impedance changes with varying $\mathrm{NO}$ and $\mathrm{O}_{2}$ concentration for an in-plane $\mathrm{Au} / \mathrm{YSZ} / \mathrm{Au}$ cell with a dense YSZ electrolyte and a porous YSZ layer separating the electrodes from the electrolyte. ${ }^{16}$ In the current work, the cell only contains dense Au-wire electrodes and porous YSZ. The Au-wire configuration isolates and clarifies the contribution of the $\mathrm{Au} /$ porous YSZ interface, which appears to have a significant impact on impedancemetric sensing of NO.

The high-frequency behavior does not change with gas concentration (either $\mathrm{O}_{2}$ or NO) and represents ohmic contributions (from leads, etc.) and resistance contributions from the ionic conduction in YSZ and related phenomena such as current constriction. Since the separation distance between the wire loops did not affect the impedance, the primary ionic contribution seems to be from the additional YSZ slurry applied on the wires, and not from the porous YSZ block. This high-frequency contribution to resistance can be approximated by the cusp between the high-frequency and low-frequency ranges at $\sim 1 \mathrm{kHz}$ in Fig. 3 . 


\section{Equivalent circuit analysis}

Equivalent circuit analysis was used to investigate behavior in the lowfrequency range $(<1 \mathrm{kHz})$, where the electrode impedance was affected by changing gas concentration $\left(\mathrm{O}_{2}\right.$ or $\left.\mathrm{NO}\right)$. Discrete arcs in the Nyquist representation are generally considered to indicate processes with distinguishable characteristic time constants $(\tau)$. For a perfect resistor and capacitor in parallel, the diameter of the arc corresponds to the magnitude of the resistance $(R)$, and $\tau=R \times C=1 / \omega_{t o p}$, where $C$ is the value of the capacitor, and $\omega_{t o p}$ is the angular frequency at the top of the arc. However, multiple phenomena often exhibit similar time constants causing the arcs to be convoluted. At least two orders of magnitude difference between time constants are necessary to produce clearly separated arcs. In addition, heterogeneity at the interfaces may also lead to a distribution of time constants, instead

of a single time constant, which has been used to explain the appearance of "depressed" arcs that deviate from ideal semicircular behavior. ${ }^{11}$

To simulate non-ideal behavior, constant phase elements (CPEs) are used in place of the capacitive components in the equivalent circuit. The CPE has the impedance relationship ${ }^{11}: Z(\omega)=\left[Y_{0}(j \omega)^{-n}\right]^{-1}$, where $Y_{0}$ is a constant, $\omega$ is angular frequency, and $n$ is a measure of arc depression. For $n=1$, there is no arc depression, and the CPE behaves like a capacitor with a value of $Y_{0}$.

The equivalent circuit used to interpret the data obtained in this study, 
shown by the inset of Fig. 4, models the impedance behavior at frequencies less than $\sim 1 \mathrm{kHz}$. The circuit consists of a resistor $\left(R_{S}\right)$ in series with two subcircuits, both of which contain a resistor $\left(R_{L F}\right)$ in parallel with a constant phase element (CPE). The subscripts "S" and "LF" stand for series and low-frequency, respectively. The value of $R_{S}$ approximates the high-frequency $(>1 \mathrm{kHz}$ ) contribution to the total cell resistance, which is unaffected by gas concentration. The first subcircuit in Fig. $4, R_{L F}^{\prime}$ and its parallel CPE $\left(Y_{0}^{\prime}\right.$ and $\left.n^{\prime}\right)$, represents behavior occurring at slightly higher frequencies (i.e., intermediate frequencies) than the second subcircuit, $R_{L F}^{\prime \prime}$ and its parallel CPE $\left(Y_{0}^{\prime \prime}\right.$ and $\left.n^{\prime \prime}\right)$. The combined values of $R_{L F}^{\prime}$ and $R_{L F}^{\prime \prime}$ correspond to the total resistance of the electrode reactions and electrode/electrolyte interfacial phenomena.

The necessity for two subcircuits to model the experimental data indicates that multiple phenomena may be occurring. The model was fit to the experimental impedance data using the partial non-linear least squares fitting routine in the Boukamp EQUIVCRT.COM software. ${ }^{21}$ A typical result for $10.5 \% \mathrm{O}_{2}$ is shown in Fig. 4. In this figure, the overall fit is shown as the solid line. The individual contributions from each subcircuit are shown as the dotted lines with the first subcircuit $\left(R_{L F}^{\prime}\right.$ and its parallel CPE, $Y_{0}^{\prime}$ and $\left.n^{\prime}\right)$ at the higher frequency and the second $\left(R_{L F}^{\prime \prime}\right.$ and its parallel CPE, $Y_{0}^{\prime \prime}$ and $\left.n^{\prime \prime}\right)$ at the lower frequency.

Note that the two subcircuits in series are used to model impedance 
behavior with and without $\mathrm{NO}$, and do not correspond directly with the $\mathrm{O}_{2}$ and $\mathrm{NO}$ reactions. The effect of changing $\mathrm{O}_{2}$ and $\mathrm{NO}$ concentrations on the impedance occurs over similar frequency ranges (see Fig. 3), so their individual contributions are not modeled with the two subcircuits. The two subcircuits in series are therefore not directly associated with the individual parallel contributions of the $\mathrm{O}_{2}$ and $\mathrm{NO}$ reactions to the total measured impedance. Instead, the two subcircuits account for the total contribution of all reactions that are occurring.

Figure 5a shows the Nyquist behavior of the same cell $(\mathrm{Au} / \mathrm{YSZ} / \mathrm{Au})$ at $650^{\circ} \mathrm{C}$ in varying $\mathrm{O}_{2}$ concentrations $(2-18.9 \%)$. Also shown are the results using the equivalent circuit model (shown as solid lines). The values calculated from the fitting procedure for each $\mathrm{O}_{2}$ concentration are shown in Table 1. For the non-ideal behavior of the CPE, the time constant $\tau$ can be approximated using the following expression: ${ }^{28}$

$$
\tau=\left(R \times Y_{0}\right)^{1 / n}
$$

The convolution of the arcs associated with the two subcircuits corresponds to the similarity in the calculated time constants, $\tau^{\prime}$ and $\tau^{\prime \prime}$. Phenomena with similar time constants are difficult to isolate and model with individual circuit elements, and the fitting with two subcircuits should be viewed as an approximation. Also, the deviation of $n$-values from ideal behavior (i.e., $n=1$ ) and the variation of $n$-values with $\mathrm{O}_{2}$ concentration may 
indicate heterogeneity and/or additional complex phenomena unaccounted for by the two subcircuits.

Using the best-fit values, the effect of oxygen partial pressure, $\mathrm{P}_{\mathrm{O}_{2}}$, on the values of the individual contributions to the electrode resistances $\left(R_{L F}^{\prime}\right.$ and $\left.R_{L F}^{\prime \prime}\right)$ is shown in Fig. 5b. $R_{S}$, which approximates the high-frequency contributions, is insensitive to $\mathrm{P}_{\mathrm{O}_{2}}$, which is expected since it accounts for ohmic contributions (from leads, etc.) and the ionic conductivity of the YSZ. Previous work by the authors has measured the $\mathrm{O}_{2}$ dependence of a symmetric $\mathrm{Au} / \mathrm{YSZ} / \mathrm{Au}$ planar cell. ${ }^{16}$ In that work, the electrode resistance appeared as a single arc with minimal arc depression $(n \sim 0.9)$, and the electrode resistance scaled as $\mathrm{P}_{\mathrm{O}_{2}}^{-0.62} \cdot{ }^{16} \mathrm{~A} \mathrm{P}_{\mathrm{O}_{2}}$ dependence of $R_{L F} \propto \mathrm{P}_{\mathrm{O}_{2}}^{-0.5}$ has been suggested when dissociative adsorption of oxygen or transport of atomic oxygen to the electrochemical reaction site are the rate-limiting steps. ${ }^{23,25,26}$

In the current work, both $R_{L F}^{\prime}$ and $R_{L F}^{\prime \prime}$ have an oxygen dependence of $\mathrm{P}_{\mathrm{O}_{2}}^{-0.37}$. Due to the uncertainty in fitting multiple convoluted arcs, only a tentative conclusion can be drawn about the rate-determining step. The current analysis therefore focuses on differences in $\mathrm{NO}$ sensitivity and $\mathrm{P}_{\mathrm{O}_{2}}$ dependence of the Au wire loop electrode in comparison to other electrode materials (Pt and $\mathrm{Ag}$ ), or with a porous microstructure (Au electrode). This study examines the role of the electrode material, porosity, and electrode/electrolyte interface. 


\section{Varying composition: $\mathrm{Pt}$ and $\mathrm{Ag}$}

Figure 6a shows the Nyquist behavior for a porous YSZ block with wrapped $\mathrm{Pt}$ wires $(\mathrm{Pt} / \mathrm{YSZ} / \mathrm{Pt})$ at $650^{\circ} \mathrm{C}$ in varying $\mathrm{O}_{2}$ concentrations $\left(7-18.9 \% \mathrm{O}_{2}\right)$. The Nyquist behavior at $2 \% \mathrm{O}_{2}$ is not shown and behaves very similarly to the $7 \% \mathrm{O}_{2}$ data. For all $\mathrm{O}_{2}$ concentrations, no changes in impedance behavior occurred with the addition of 100 ppm NO.

The solid lines in Fig. 6a are the best fit to the data using the equivalent circuit model in Fig. 4. Unlike with the Au-wire electrodes, only one subcircuit, $R_{L F}^{\prime}$ and its parallel $\operatorname{CPE}\left(Y_{0}^{\prime}\right.$ and $\left.n^{\prime}\right)$, was necessary to adequately model the behavior of the Pt/YSZ/Pt cell. Smaller $n$-values were obtained $(n \sim 0.5)$, which may indicate severe inhomogeneity or multiple processes that are not able to be resolved clearly as separate arcs. The calculated parameters from the fitting procedure are listed in Table 2. Similar to the Au-wire electrodes, a distinct cusp is evident separating two frequency ranges (see inset of Fig. 6a), where the higher frequency range is unaffected by changes in gas concentration. The resistance values measured for Pt-wire electrodes are significantly smaller than the resistance values for Au-wire electrodes (see Fig. 3) at identical gas concentrations. For Pt-wire electrodes in $10.5 \% \mathrm{O}_{2}, R_{S}$ and $R_{L F}^{\prime}$ are $\sim 2$ and $\sim 0.1 \mathrm{k} \Omega$, respectively, as seen in Fig. 6a. In contrast, for Au-wire electrodes, $R_{S}$ is $\sim 10 \mathrm{k} \Omega$, and the combined values of $R_{L F}^{\prime}$ and $R_{L F}^{\prime \prime}$ are $\sim 9 \mathrm{k} \Omega$, as shown in Fig. 3. Figure 6a also shows that the electrode impedance for the Pt/YSZ/Pt cell occurs at 
higher frequencies $(\sim 1 \mathrm{kHz})$ than the corresponding behavior using Au-wire electrodes $(\sim 10$ to $100 \mathrm{~Hz}$, see Fig. 3).

The most pronounced difference between the $\mathrm{Au} / \mathrm{YSZ} / \mathrm{Au}$ and $\mathrm{Pt} / \mathrm{YSZ} / \mathrm{Pt}$ cell behaviors is how the electrode resistance varies with $\mathrm{O}_{2}$ concentration. The total electrode resistance for the Au-wire cell, given by the combined values of $R_{L F}^{\prime}$ and $R_{L F}^{\prime \prime}$, decreases with increasing $\mathrm{O}_{2}$ concentration, while the opposite trend is evident for the Pt-wire cell. Figure $6 \mathrm{~b}$ demonstrates the effect of $\mathrm{P}_{\mathrm{O}_{2}}$ on the electrode resistance $\left(R_{L F}^{\prime}\right)$ for Pt/YSZ/Pt. Over the $\mathrm{O}_{2}$ concentration range $7-18.9 \%$, the electrode resistance is proportional to $\mathrm{P}_{\mathrm{O}_{2}}^{0.17}$. Recall that Fig. 5b showed a $\mathrm{P}_{\mathrm{O}_{2}}^{-0.37}$ dependence for the $\mathrm{Au}$-wire cell. For the Pt-wire cell, the data show that the $\mathrm{P}_{\mathrm{O}_{2}}^{0.17}$ dependence may no longer apply for decreasing $\mathrm{O}_{2}$ concentrations, where the electrode resistance increases slightly from 7 to $2 \% \mathrm{O}_{2}$. Since there is only one data point to characterize this change in behavior, only a tentative conclusion can be made about changes in the sign of the power-law exponent at lower $\mathrm{O}_{2}$ concentrations. Nevertheless, the complex behavior of the Pt/YSZ/Pt cell with two apparently different power-law exponents at lower and higher $\mathrm{O}_{2}$ concentrations seems to agree with previous work where charge transfer at the triple phase boundary is the rate-determining step.

$1 / 4$ and $-1 / 4$ power-law exponents have been attributed to a rate-limiting charge transfer step at the triple phase boundary. ${ }^{23,29,30}$ The $\mathrm{P}_{O_{2}}^{\frac{1}{4}}$ and $\mathrm{P}_{\mathrm{O}_{2}}^{-\frac{1}{4}}$ dependences are based on Langmuir-type dissociative $\mathrm{O}_{2}$ adsorption where 
the $1 / 4$ power-law exponent occurs at low temperature and/or in the high $\mathrm{P}_{\mathrm{O}_{2}}$ range, and the $-1 / 4$ power-law exponent occurs at high temperature and/or in the low $\mathrm{P}_{\mathrm{O}_{2}}$ range. ${ }^{23,29,30}$ Previous work with Pt/YSZ films measured the exchange current density and demonstrated the gradual transition between the $1 / 4$ and $-1 / 4$ electrode behavior over a range of temperatures and $\mathrm{O}_{2}$ concentrations. ${ }^{31}$ In the current work, the Pt/YSZ/Pt cell may also be exhibiting this type of transition associated with a rate-limiting charge transfer step.

Figure 7 shows the Nyquist behavior of the porous YSZ block with wrapped $\mathrm{Ag}$ wires $(\mathrm{Ag} / \mathrm{YSZ} / \mathrm{Ag})$ at $650^{\circ} \mathrm{C}$ in $10.5 \% \mathrm{O}_{2}$. Unlike both the Au- and Pt-wire electrodes, only a single arc is evident that occurs in the high-frequency range $(>10 \mathrm{kHz})$. This impedance behavior was unaffected by either changes in $\mathrm{O}_{2}$ or $\mathrm{NO}$ concentration. Since the single arc occurs at higher frequencies and does not change with gas concentration, the behavior can be attributed to ohmic contributions and resistance contributions from the YSZ and current constriction. The high-frequency resistance value for $\mathrm{Ag}$-wire electrodes is also much larger $(\sim 100 \mathrm{k} \Omega)$ compared to values seen in either the Au- $(\sim 10 \mathrm{k} \Omega)$ or Pt-wire $(\sim 2 \mathrm{k} \Omega)$ electrodes.

The large impedance of the Ag-wire electrode was likely due to current constriction contributions from the imperfect contact between $\mathrm{Ag}$ and YSZ, which may have been caused by thermal expansion mismatch. Table 4 lists the linear thermal expansion coefficients for YSZ, Au, Pt, and Ag. 
$\mathrm{Ag}$, compared to $\mathrm{Au}$ and $\mathrm{Pt}$, has the largest thermal expansion mismatch with YSZ, which has an expansion coefficient about $10.5 \times 10^{-6} \mathrm{~K}^{-1}{ }^{32}$ The large mismatch probably allowed minimal contact area between the Ag wire and the porous YSZ leading to the large impedance of the high-frequency contribution. The Ag-wire electrode did produce small values for the lower frequency electrode resistance (occurring $<1 \mathrm{kHz}$ ), which were not clearly resolved due to the dominance of the large impedance of the high-frequency contribution. The small electrode resistance (low $\mathrm{O}_{2}$ overpotential) of $\mathrm{Ag}$ with YSZ has been attributed to the high solubility and mobility of $\mathrm{O}_{2}$ within the Ag bulk. ${ }^{33,34}$

Comparison of the behavior of Au-, Pt-, and Ag-wire wrapped porous YSZ cells shows that only Au-wire electrodes demonstrate sensitivity to NO. For the case of Ag, the large thermal expansion mismatch with YSZ damages the interface during processing and causes only the high-frequency behavior to be discerned, which does not vary with $\mathrm{O}_{2}$ or $\mathrm{NO}$ concentration. For $\mathrm{Au}$ and Pt, a closer thermal expansion match with YSZ (see Table 4) allows the values of the electrode resistance at lower frequencies to be examined separately from the higher frequency behavior.

Both $\mathrm{Au}$ and $\mathrm{Pt}$ exhibit a power-law dependence for the variation of the electrode resistance with $\mathrm{O}_{2}$ concentration. The power-law dependence found in previous work (see Ref. [16]) with dense $\mathrm{Au}$ electrodes $\left(\mathrm{P}_{\mathrm{O}_{2}}^{-0.62}\right)$ and in the current work with $\mathrm{Au}$-wire electrodes $\left(\mathrm{P}_{\mathrm{O}_{2}}^{-0.37}\right)$ differ significantly 
from the behavior of the Pt-wire electrode $\left(\mathrm{P}_{\mathrm{O}_{2}}^{0.17}\right)$. The difference in $\mathrm{O}_{2}$ dependence indicates a difference in the rate-limiting step.

For Pt, the rate-limiting step appears to occur at the triple phase boundary or reaction site, whereas for the Au-wire electrode, the reaction is more likely limited by gas adsorption and/or transport to the reaction site. A possible explanation for the difference is the relative catalytic activity for the $\mathrm{O}_{2}$ reduction reaction (Eq. 1). Au is a poor catalyst compared to $\mathrm{Pt}$, which is known to be a very effective $\mathrm{O}_{2}$ reduction catalyst. More work is needed to clarify the mechanisms involved and the role of the $\mathrm{O}_{2}$ reduction catalytic activity of the electrode material.

The difference in NO sensitivity for $\mathrm{Au}$ and $\mathrm{Pt}$ may be related to the relative catalytic reaction rates for the $\mathrm{O}_{2}$ and $\mathrm{NO}_{x}$ reactions. Based on parallel contributions from $\mathrm{O}_{2}$ and $\mathrm{NO}_{x}$ reactions to the total measured impedance, increasing the contribution of the $\mathrm{O}_{2}$ reaction relative to the $\mathrm{NO}_{x}$ reaction would then decrease the influence of the $\mathrm{NO}_{x}$ reaction path, i.e., reduce $\mathrm{NO}_{x}$ sensitivity. For $\mathrm{Pt}$, the high $\mathrm{O}_{2}$ catalytic activity may be responsible for the different rate-limiting step compared to $\mathrm{Au}$ and also for an increase in the contribution from the $\mathrm{O}_{2}$ reaction compared to $\mathrm{NO}_{x}$. Similarly, the $\mathrm{Ag}$ electrode, due to the high solubility and mobility of $\mathrm{O}_{2}$ within the Ag bulk, may also cause an increase in the contribution of the $\mathrm{O}_{2}$ reaction relative to $\mathrm{NO}_{x}$. Differences in the rate-limiting step for the $\mathrm{O}_{2}$ reaction, and its effect on the ratio between the contributions of $\mathrm{O}_{2}$ and 
$\mathrm{NO}_{x}$ reactions to the total measured impedance, seems to be an important factor in determining the sensitivity to NO.

\section{Varying microstructure: dense and porous $\mathrm{Au}$}

The role of the Au electrode microstructure was investigated using a symmetric cell consisting of the porous YSZ slab in contact with two dense $\mathrm{Au}$ plates, with and without a porous $\mathrm{Au}$ interlayer between the Au plate and porous YSZ, as shown in Fig. 2b. The porous Au interlayer served to increase the electrode/electrolyte interfacial contact area and the amount of electrode surface area compared to the dense Au-wire electrodes. The porosity of the YSZ slab should allow sufficiently fast gas diffusion to the interface so that the relevant geometrical factor is more likely the entire $2 \mathrm{D}$ area of the porous $\mathrm{Au} / \mathrm{YSZ}$ interface as opposed to the 1D line where gas enters between the Au plate and porous YSZ slab.

Figure 8a shows the Nyquist behavior of the symmetric cell $(\mathrm{Au} /$ porous $\mathrm{Au} / \mathrm{YSZ} /$ porous $\mathrm{Au} / \mathrm{Au})$ in varying $\mathrm{O}_{2}$ concentrations $\left(2-18.9 \% \mathrm{O}_{2}\right)$ at $650^{\circ} \mathrm{C}$. The cell with porous $\mathrm{Au}$ was insensitive to NO (data not shown). The solid lines in Fig. 8a are the best fit using the equivalent circuit model in Fig.

4. Table 3 lists the calculated parameters. In analogy to the Pt/YSZ/Pt cell with wrapped dense wires, the behavior of the cell with porous Au was adequately described using only a single subcircuit, $R_{L F}^{\prime}$ and its parallel CPE $\left(Y_{0}^{\prime}\right.$ and $\left.n^{\prime}\right)$. Also, the impedance behavior described by the single subcircuit for the cell with porous Au occurred at higher frequencies $(\sim 100$ 
$\mathrm{Hz}$ to $1 \mathrm{kHz})$ compared to the $\mathrm{Au}$ wire sample ( 10 to $100 \mathrm{~Hz})$.

Figure 8b shows the effect of $\mathrm{P}_{\mathrm{O}_{2}}$ on the electrode resistance. $R_{L F}^{\prime}$ is proportional to $\mathrm{P}_{\mathrm{O}_{2}}^{-0.13}$ over the $\mathrm{O}_{2}$ concentration range $2-18.9 \%$. As previously discussed with the Pt electrode, power-law exponents ranging from $-1 / 4$ to 1/4 have been attributed to charge transfer at the triple phase boundary as the rate-determining step. ${ }^{23,29,30}$ The $\mathrm{P}_{\mathrm{O}_{2}}$ dependences of the cells with either porous $\mathrm{Au}$ or dense Pt wire electrodes seem to suggest the same ratelimiting step. However, for similar $\mathrm{O}_{2}$ concentration ranges (7-18.9\%), the Pt wire-wrapped porous YSZ exhibits behavior consistent with low temperature or high $\mathrm{O}_{2}$ concentration (i.e., positive power-law exponents, see Fig. 6b), while the cell with porous Au exhibits behavior consistent with high temperature or low $\mathrm{O}_{2}$ concentration (i.e., negative power-law exponents, see Fig. $8 b$ ). The difference in behavior may be indicating the better catalytic activity of the $\mathrm{Pt}$ electrode for the $\mathrm{O}_{2}$ reaction compared to the porous $\mathrm{Au}$.

To clarify the effect of the porous Au electrode, two additional experiments were conducted. Since different geometries were used to investigate the wire-wrapped samples discussed previously (see Figs. 2a and b), a control sample without the porous Au interlayer was tested. The symmetric control sample (Au plate/YSZ/Au plate) consisted of the porous YSZ slab in contact with two $\mathrm{Au}$ plates. This is analogous to the Au wire-wrapped sample albeit with different contact areas. Figure 9 shows the Nyquist be- 
havior for $\mathrm{Au}$ plate/YSZ/Au plate at $700^{\circ} \mathrm{C}$ in $10.5 \% \quad \mathrm{O}_{2}, 10.5 \% \mathrm{O}_{2}+$ $100 \mathrm{ppm} \mathrm{NO}$, and $18.9 \% \mathrm{O}_{2}$. The higher temperature was used to allow measurement of the very large impedance values $(>500 \mathrm{k} \Omega$ ) caused by the reduced contact area, and therefore more limited electrochemical reaction sites, between the Au plate and the YSZ. In the wire-wrapped samples, better contact was achieved by applying additional YSZ slurry to the wires. As anticipated, the Au plate/YSZ/Au plate cell shows impedancemetric sensing of NO, where the impedance decreased with the introduction of $100 \mathrm{ppm}$ NO. Furthermore, a rough approximation for the $\mathrm{O}_{2}$ dependence based on the behavior of the $\mathrm{Au}$ plate/YSZ/Au plate cell, using equivalent circuit parameters calculated from data for 10.5 and $18.9 \% \mathrm{O}_{2}$, was found to yield $\mathrm{P}_{\mathrm{O}_{2}}^{-0.42}$. Therefore, the effect of the porous $\mathrm{Au}$ electrode is to change the $\mathrm{O}_{2}$ dependence and the rate-determining step.

The second experiment involved clarifying the effect of reducing the number of electrochemical reaction sites (i.e., triple phase boundary length) between the $\mathrm{Au}$ and YSZ. From the wire and dense plate experiments, cells exhibiting NO sensitivity also had large impedance values $(>10 \mathrm{k} \Omega$ ) that indicate relatively low population of electrochemical reaction sites, while sensors with smaller impedance values were not sensitive to NO. For the cell with porous $\mathrm{Au}$ interlayers, the lack of NO sensitivity was due to an increase in the ratio of electrode surface area to triple phase boundary, which resulted in a different rate-limiting mechanism. The lack of NO sensitivity 
should not be attributed to increasing the triple phase boundary length. To demonstrate that the change in rate-limiting mechanism is responsible for predicting NO sensitivity, and not changes in the triple phase boundary, another symmetric cell with porous $\mathrm{Au}$ was tested that had a significantly reduced area of the porous $\mathrm{Au}$ interlayer. The result was a test cell with much larger impedance values due to the a smaller contact area between the porous $\mathrm{Au}$ and YSZ compared to the original cell.

Figure 10a shows the Nyquist behavior of the sample with the reduced area of porous $\mathrm{Au}$ interlayers in varying $\mathrm{O}_{2}$ concentrations $\left(2-18.9 \% \mathrm{O}_{2}\right)$ at $700^{\circ} \mathrm{C}$. Again, the higher temperature was used to allow measurements at the large impedance values, which increased to $>100 \mathrm{k} \Omega$. No change in impedance behavior occurred with the addition of $100 \mathrm{ppm}$ NO. Thus, the cell with porous $\mathrm{Au}$ remained insensitive to $\mathrm{NO}$ even with the significantly reduced number of reaction sites. The $\mathrm{O}_{2}$ dependence of the high-impedance cell with porous $\mathrm{Au}$, using calculated equivalent circuit parameters, was found to be given by $\mathrm{P}_{\mathrm{O}_{2}}^{-0.28}$. The $\mathrm{P}_{\mathrm{O}_{2}}$ dependence of the high-impedance cell with porous $\mathrm{Au}$ differs from the the low-impedance cell $\left(\mathrm{P}_{\mathrm{O}_{2}}^{-0.13}\right)$, although both values are in the range attributable to charge transfer at the triple phase boundary as the rate-limiting mechanism (power-law exponents ranging from $-1 / 4$ to $1 / 4)$.

The results of the low- and high-impedance cells with porous Au interlayers indicate that increasing or decreasing the triple phase boundary affects 
the $\mathrm{O}_{2}$ reaction rate and magnitude of the measured impedance, but does not necessarily affect the rate-limiting mechanism or NO sensitivity. This suggests that the rate-limiting mechanism may provide information about the $\mathrm{NO}$ sensitivity and the relative contributions of $\mathrm{O}_{2}$ and $\mathrm{NO}$ reactions to the measured impedance. Modification of the electrode surface microstructure by increasing the surface area relative to the triple phase boundary (i.e., porous $\mathrm{Au}$ vs. dense $\mathrm{Au}$ ) seems to alter the rate-limiting mechanism for the $\mathrm{O}_{2}$ reaction, indicating an increase in the relative contribution of the $\mathrm{O}_{2}$ reaction compared to $\mathrm{NO}$ and the inability to sense NO.

\section{Conclusions}

For impedancemetric NO sensors based on YSZ-electrolyte, both the electrode composition and microstructure alter the sensitivity. Only dense $\mathrm{Au}$ electrodes exhibit sensitivity to NO, while other compositions for dense wire electrodes (Pt and $\mathrm{Ag}$ ) and porous $\mathrm{Au}$ electrodes do not respond to changes in NO concentration. The NO sensitivity seems to be related to the ratedetermining step for the $\mathrm{O}_{2}$ reaction. The importance of the $\mathrm{O}_{2}$ reaction may be due to its larger contribution, compared to $\mathrm{NO}_{x}$, to the overall measured impedance. For parallel contributions from $\mathrm{NO}_{x}$ and $\mathrm{O}_{2}$ reactions, the dominant $\mathrm{O}_{2}$ reaction determines if changes in the $\mathrm{NO}_{x}$ concentration will influence the overall measured impedance.

Both dense Pt wire and porous Au electrodes show impedance behavior 
consistent with charge transfer at the triple phase boundary as the ratelimiting step for the $\mathrm{O}_{2}$ reaction. Dense $\mathrm{Au}$ electrodes show impedance behavior consistent with either adsorption or diffusion as the rate-limiting step for the $\mathrm{O}_{2}$ reaction. The results suggest that a rate-limiting step for the $\mathrm{O}_{2}$ reaction occurring away from the triple phase boundary may be important for impedancemetric NO sensing.

\section{Acknowledgements}

This work was performed under the auspices of the U. S. Department of Energy by the University of California, Lawrence Livermore National Laboratory under Contract No. W-7405-Eng-48. Support for the work at the University of Pennsylvania was provided by the U.S. Department of Energy's Hydrogen Fuel Initiative (grant DE-FG02-05ER15721). Two of the coauthors (RSG and LPM) are also supported through the DOE Office of Freedom Car and Vehicle Technologies. We gratefully acknowledge the support of the Program Managers, Rogelio Sullivan and Jerry Gibbs. Contributions from D. J. Kubinsky and R. E. Soltis, both from Ford Motor Company, are also acknowledged. 


\section{References}

1. F. Ménil, V. Coillard, and C. Lucat, Sens. Actuators, B, 67, 1 (2000).

2. W. Göpel, G. Reinhardt, and M. Rösch, Solid State Ionics, 136-137, $519(2000)$.

3. J. Riegel, H. Neumann, H. -M. Wiedenmann, Solid State Ionics, 152153, 783 (2002).

4. R. Moos, Int. J. Appl. Ceram. Technol., 2, 401 (2005).

5. S. Akbar, P. Dutta, and C. Lee, Int. J. Appl. Ceram. Technol., 3, 302 (2006).

6. S. Somov, G. Reinhardt, U. Guth, and W. Göpel, Sen. Actuators, B, 35-36, 409 (1996).

7. V. Coillard, H. Debéda, C. Lucat, and F. Ménil, Sen. Actuators, B, 78, 113 (2001).

8. D. L. West, F. C. Montgomery, and T. R. Armstrong, Sen. Actuators, $B, \mathbf{1 1 1 - 1 1 2 ,} 84$ (2005).

9. D. L. West, F. C. Montgomery, and T. R. Armstrong, J. Electrochem. Soc., 153, H23 (2006). 
10. S. -W. Song, L. P. Martin, R. S. Glass, E. P. Murray, J. H. Visser, R. E. Soltis, R. F. Novak, and D. J. Kubinski, J. Electrochem. Soc., 153, H171 (2006)

11. J. R. Macdonald, Impedance Spectroscopy: Emphasizing Solid Materials and Systems, p. 5, John Wiley \& Sons, New York (1987).

12. N. Miura, M. Nakatou, and S. Zhuiykov, Ceram. Int., 30, 1135 (2004).

13. N. Miura, M. Nakatou, and S. Zhuiykov, Sen. Actuators, B, 93, 221 (2003).

14. N. Wu, Z. Chen, J. Xu, M. Chyu, and S.X. Mao, Sens. Actuators, B, 110, $49(2005)$.

15. L. P. Martin, L. Y. Woo, and R. S. Glass, J. Electrochem. Soc., 154, J97 (2007).

16. L. Y. Woo, L. P. Martin, R. S. Glass, and R. J. Gorte, J. Electrochem. Soc., 154, J129 (2007).

17. J. Yoo, F. M. Van Assche, and E. D. Wachsman, J. Electrochem. Soc., 153, H115 (2006).

18. M. Boaro, J. M. Vohs, and R. J. Gorte, J. Am. Ceram. Soc., 86, 395 (2003).

19. S. Jung, C. Lu, H. He, K. Ahn, R. J. Gorte, and J. M. Vohs, J. Power Sources, 152, 42 (2006). 
20. W. Wang, M. D. Gross, J. M.Vohs, and R. J. Gorte, J. Electrochem. Soc., 154, B439 (2007).

21. B. A. Boukamp, Equivalent Circuit (EQUIVCRT.PAS), University of Twente, Dept. of Chemical Engineering, The Netherlands (1990).

22. S. Pizzini, in Fast Ion Transport in Solids, W. van Gool, Editor, p. 461, North-Holland/American Elsevier, Amsterdam (1973).

23. Y. Takeda, R. Kanno, M. Noda, Y. Tomida, and O. Yamamoto, J. Electrochem. Soc, 134, 2656 (1987).

24. O. J. Velle, T. Norby, and P. Kofstad, Solid State Ionics, 47, 161 (1991).

25. H. Fukunaga, M. Koyama, N. Takahashi, C. Wen, and K. Yamada, Solid State Ionics, 132, 279 (2000).

26. M. Koyama, C. Wen, T. Masuyama, J. Otomo, H. Fukunaga, K. Yamada, K. Euguchi, and H. Takahashi, J. Electrochem. Soc., 148, A795 (2001).

27. A. Ringuedé and J. Fouletier, Solid State Ionics, 139, 167 (2001).

28. A. -K. Meland, D. Bedeaux, and S. Kjelstrup, J. Phys. Chem. B, 109, $21380(2005)$.

29. D. Y. Wang and A. S. Nowick, J. Electrochem. Soc., 126, 1155 (1979). 
30. C. G. Vayenas, S. I. Bebelis, I. V. Yentekakis, and S. N. Neophytides, in The CRC handbook of solid state electrochemistry, P. J. Gellings and H. J. M. Bouwmeester, Editors, p. 445, CRC Press, New York (1997).

31. M. Manton, Ph.D. thesis, MIT, Cambridge, MA, 1984.

32. N. Q. Minh, J. Am. Ceram. Soc., 76, 563 (1993).

33. J. Van Herle and A. J. McEvoy, J. Phys. Chem. Solids, 55, 339 (1994).

34. S. P. S. Badwal, M. J. Bannister, and M. J. Murray, J. Electroanal. Chem., 168, 363 (1984).

35. "Thermal and Physical Properties of Pure Metals", in CRC Handbook of Chemistry and Physics, Internet Version 2007, (87th Edition), David R. Lide, ed., Taylor and Francis, Boca Raton, FL. 


\section{List of Figures}

Fig. 1: SEM pictures of (a) the rectangular porous YSZ slab and (b) the YSZ slurry applied on wires.

Fig. 2: Schematic of (a) wire setup to investigate composition ( $\mathrm{Au}, \mathrm{Pt}$, and $\mathrm{Ag}$ ) and (b) plate setup to investigate microstructure (dense and porous $\mathrm{Au})$.

Fig. 3: Nyquist plot of $\mathrm{Au} / \mathrm{YSZ} / \mathrm{Au}$ cell at $650^{\circ} \mathrm{C}$ in $10.5 \% \mathrm{O}_{2}, 10.5 \% \mathrm{O}_{2}$ with $100 \mathrm{ppm} \mathrm{NO}$, and $18.9 \% \mathrm{O}_{2}$. Numbers corresponding to darkened points represent log of frequency in $\mathrm{Hz}$.

Fig. 4: Nyquist plot of $\mathrm{Au} / \mathrm{YSZ} / \mathrm{Au}$ cell at $650^{\circ} \mathrm{C}$ in $10.5 \% \mathrm{O}_{2}$ and the equivalent circuit model used to calculate the best-fit (solid line), which consists of a resistor $\left(R_{S}\right)$ in series with two subcircuits. The first subcircuit consists of $R_{L F}^{\prime}$ and its parallel constant phase element (CPE: $Y_{0}^{\prime}$ and $n^{\prime}$ ) and represents behavior at slightly higher frequencies than the second subcircuit, which consists of $R_{L F}^{\prime \prime}$ and its parallel CPE $\left(Y_{0}^{\prime \prime}\right.$ and $\left.n^{\prime \prime}\right)$. The subscripts "S" and "LF" stand for series and low-frequency, respectively. Individual contributions from each subcircuit are shown as dotted lines.

Fig. 5: (a) Nyquist plot of $\mathrm{Au} / \mathrm{YSZ} / \mathrm{Au}$ cell at $650^{\circ} \mathrm{C}$ in varying $\mathrm{O}_{2}$ concentrations (2-18.9\%) and the calculated best-fit to the equivalent circuit model (solid lines). (b) The $\mathrm{P}_{O_{2}}$ dependence of $R_{L F}^{\prime}$ and $R_{L F}^{\prime \prime}$.

Fig. 6: (a) Nyquist plot of $\mathrm{Pt} / \mathrm{YSZ} / \mathrm{Pt}$ cell at $650^{\circ} \mathrm{C}$ in varying $\mathrm{O}_{2}$ concentrations (7-18.9\%) and the calculated best-fit to the equivalent circuit model 
(solid lines). (b) The $\mathrm{P}_{\mathrm{O}_{2}}$ dependence of $R_{L F}^{\prime}$.

Fig. 7: Nyquist plot of $\mathrm{Ag} / \mathrm{YSZ} / \mathrm{Ag}$ cell at $650^{\circ} \mathrm{C}$ in $10.5 \% \mathrm{O}_{2}$ and the calculated best-fit to the equivalent circuit model (solid line).

Fig. 8: Nyquist plot of porous $\mathrm{Au}$ electrode $(\mathrm{Au} /$ porous $\mathrm{Au} / \mathrm{YSZ} /$ porous $\mathrm{Au} / \mathrm{Au})$ cell at $650^{\circ} \mathrm{C}$ in varying $\mathrm{O}_{2}$ concentrations $(2-18.9 \%)$ and the calculated best-fit to the equivalent circuit model (solid lines). (b) The $\mathrm{P}_{\mathrm{O}_{2}}$ dependence of $R_{L F}^{\prime}$.

Fig. 9: Nyquist plot of $\mathrm{Au}$ plate/YSZ/Au plate cell at $700^{\circ} \mathrm{C}$ in $10.5 \% \mathrm{O}_{2}$, $10.5 \% \mathrm{O}_{2}$ with 100 ppm NO, and $18.9 \% \mathrm{O}_{2}$, and the calculated best-fit to the equivalent circuit model (solid lines).

Fig. 10: Nyquist plot of porous $\mathrm{Au}$ electrode (Au/porous $\mathrm{Au} / \mathrm{YSZ} /$ porous $\mathrm{Au} / \mathrm{Au}$ ) cell with significantly reduced contact area at $700^{\circ} \mathrm{C}$ in varying $\mathrm{O}_{2}$ concentrations (2-18.9\%) and the calculated best-fit to the equivalent circuit model (solid lines). (b) The $\mathrm{P}_{O_{2}}$ dependence of $R_{L F}^{\prime}$. 


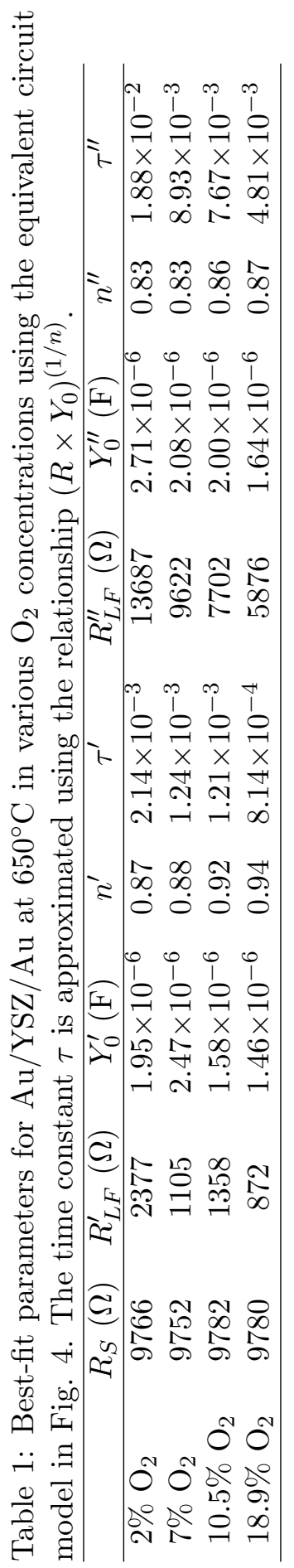


Table 2: Best-fit parameters for $\mathrm{Pt} / \mathrm{YSZ} / \mathrm{Pt}$ at $650^{\circ} \mathrm{C}$ in various $\mathrm{O}_{2}$ concentrations using the equivalent circuit model in Fig. 4.

\begin{tabular}{lcccc}
\hline & $R_{S}(\Omega)$ & $R_{L F}^{\prime}(\Omega)$ & $Y_{0}^{\prime}(\mathrm{F})$ & $n^{\prime}$ \\
\hline $2 \% \mathrm{O}_{2}$ & 2100 & 133 & $3.38 \times 10^{-5}$ & 0.51 \\
$7 \% \mathrm{O}_{2}$ & 2108 & 127 & $2.63 \times 10^{-5}$ & 0.56 \\
$10.5 \% \mathrm{O}_{2}$ & 2113 & 140 & $2.61 \times 10^{-5}$ & 0.57 \\
$18.9 \% \mathrm{O}_{2}$ & 2122 & 151 & $2.08 \times 10^{-5}$ & 0.61 \\
\hline
\end{tabular}

Table 3: Best-fit parameters for porous $\mathrm{Au}$ electrodes at $650^{\circ} \mathrm{C}$ in various $\mathrm{O}_{2}$ concentrations using the equivalent circuit model in Fig. 4.

\begin{tabular}{lcccc}
\hline & $R_{S}(\Omega)$ & $R_{L F}^{\prime}(\Omega)$ & $Y_{0}^{\prime}(\mathrm{F})$ & $n^{\prime}$ \\
\hline $2 \% \mathrm{O}_{2}$ & 1613 & 386 & $1.56 \times 10^{-5}$ & 0.68 \\
$10.5 \% \mathrm{O}_{2}$ & 1612 & 322 & $1.22 \times 10^{-5}$ & 0.71 \\
$18.9 \% \mathrm{O}_{2}$ & 1621 & 284 & $1.05 \times 10^{-5}$ & 0.73 \\
\hline
\end{tabular}

Table 4: Linear thermal expansion coefficients $(\alpha)$ for $\mathrm{YSZ}^{32}$ and metal electrodes at $25^{\circ} \mathrm{C} .{ }^{35}$

\begin{tabular}{cc} 
Composition & $\alpha \times 10^{6}\left(\mathrm{~K}^{-1}\right)$ \\
\hline YSZ & $\sim 10.5$ \\
$\mathrm{Au}$ & 14.2 \\
$\mathrm{Pt}$ & 8.8 \\
$\mathrm{Ag}$ & 18.9 \\
\hline
\end{tabular}




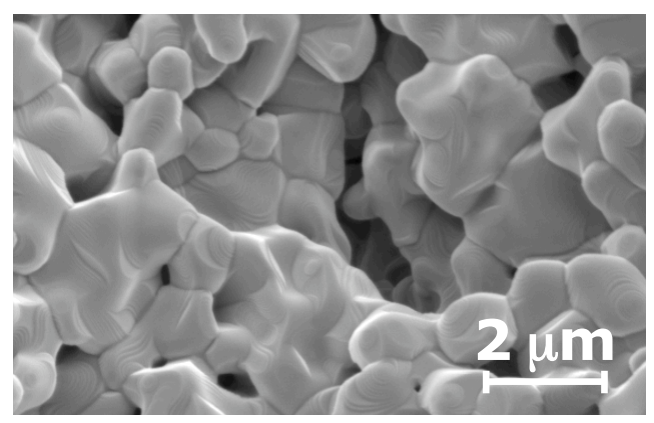

(a)

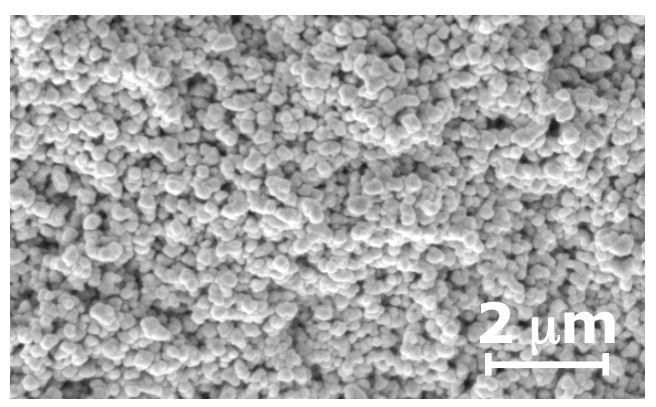

(b)

Figure 1: 


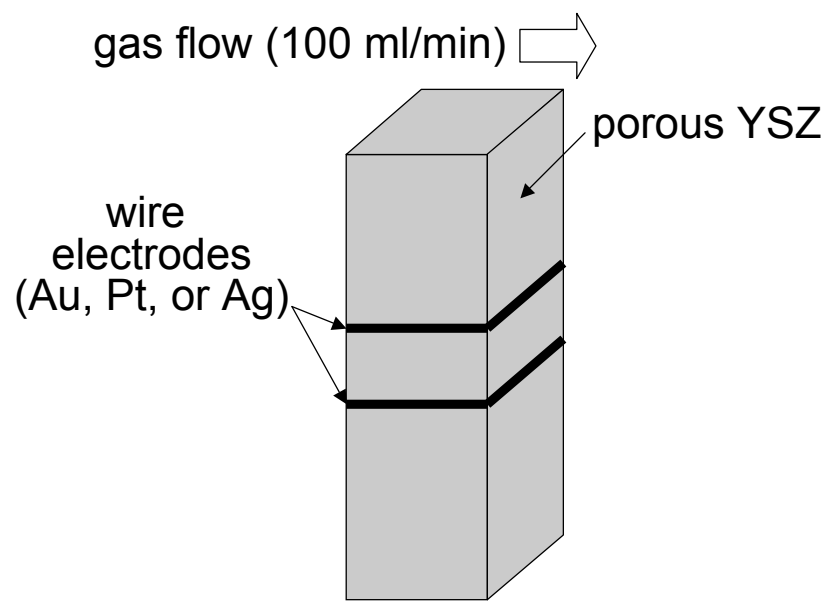

(a)

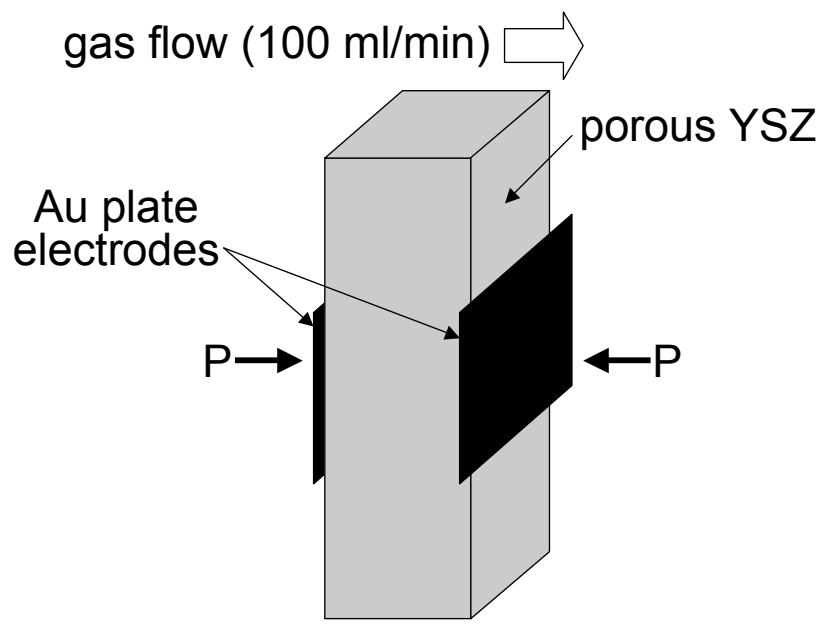

(b)

Figure 2: 


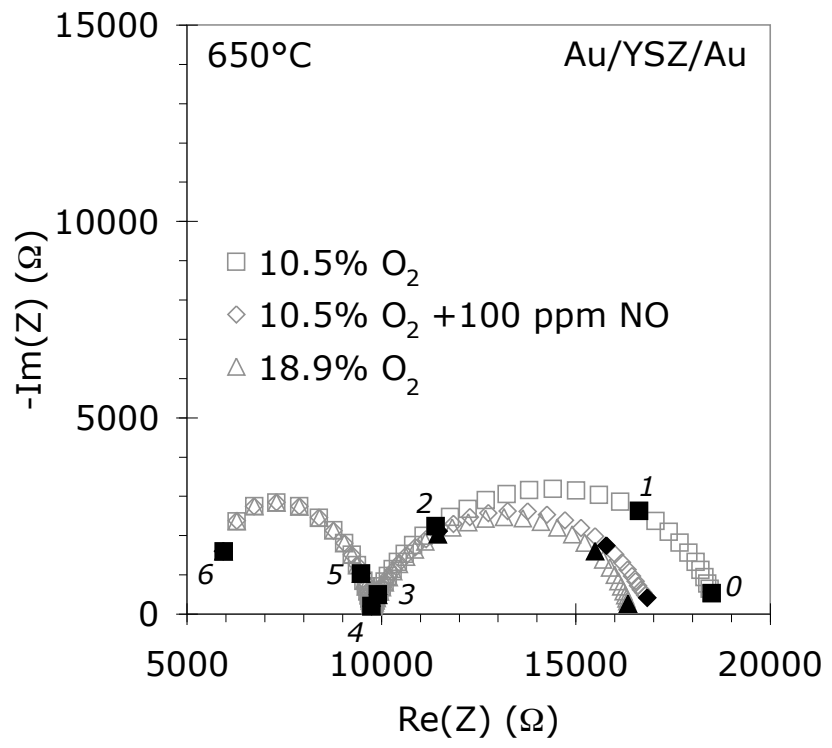

Figure 3:

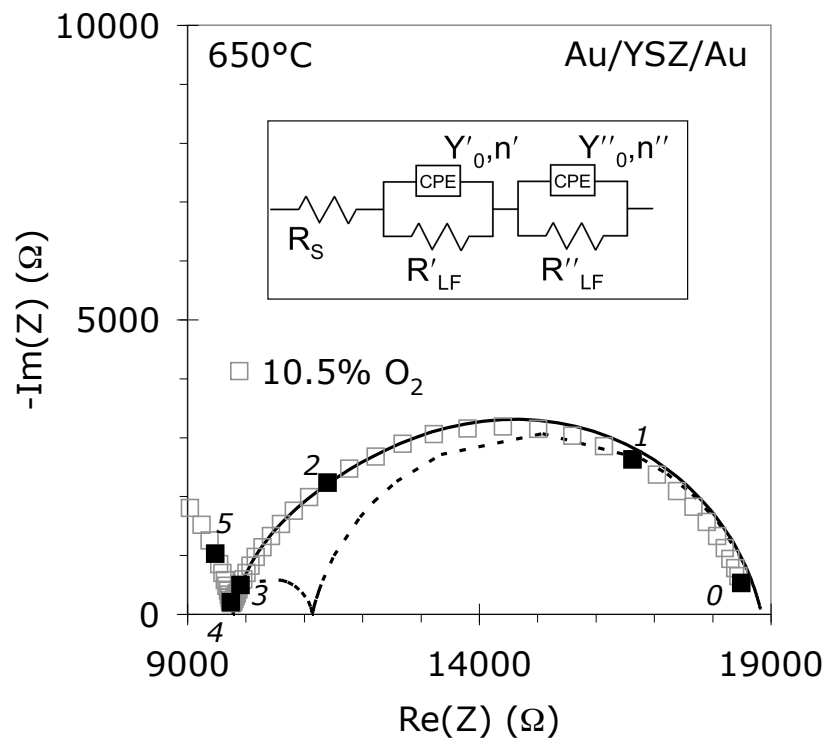

Figure 4: 


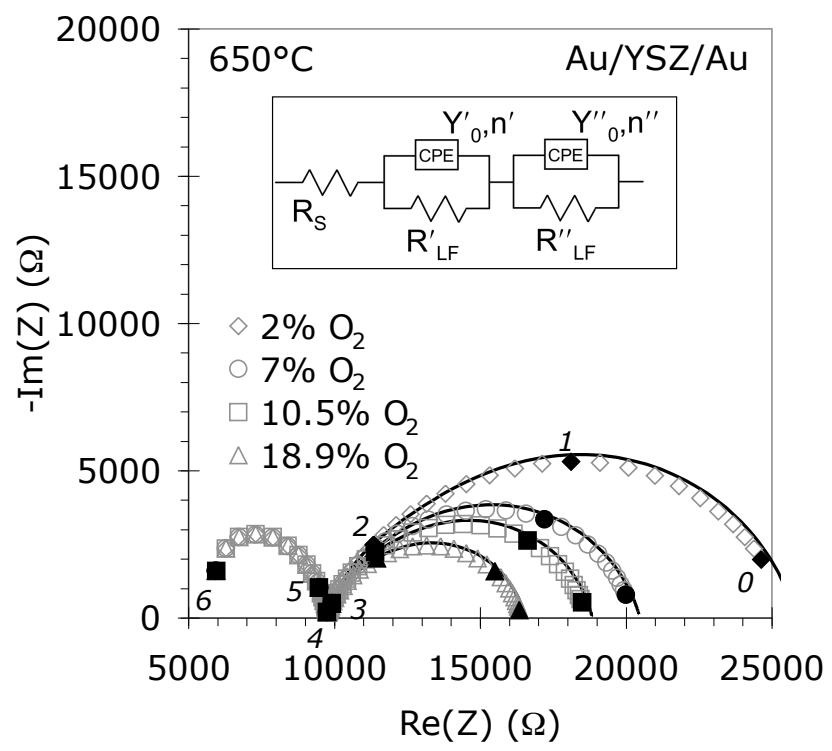

(a)

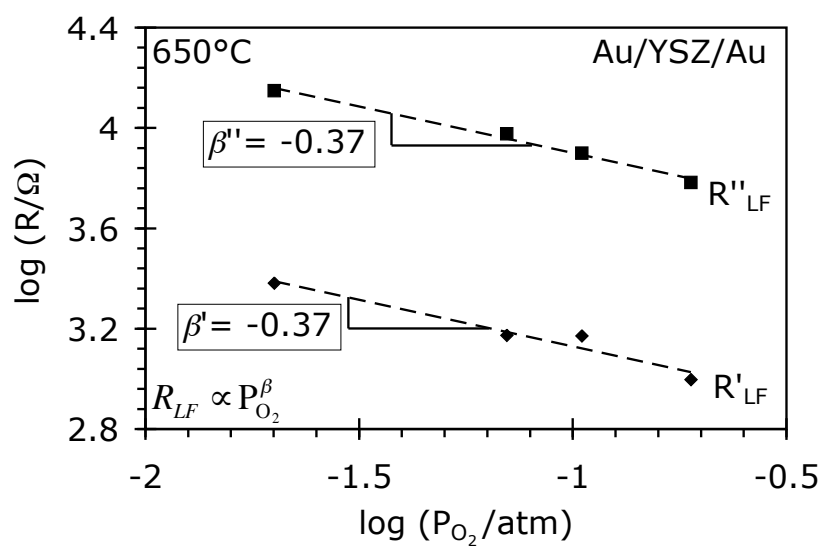

(b)

Figure 5: 


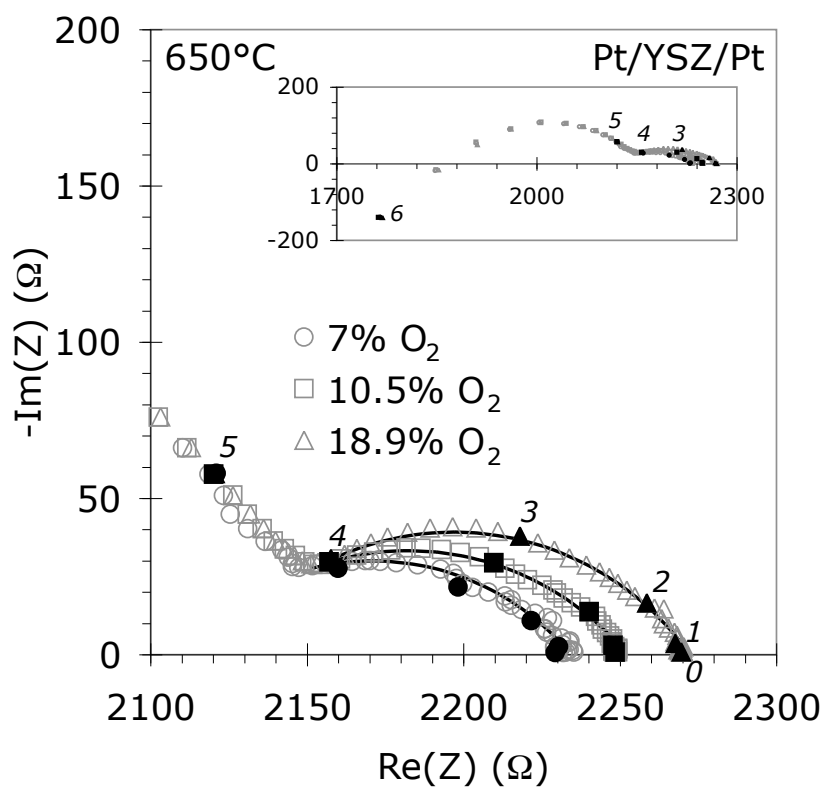

(a)

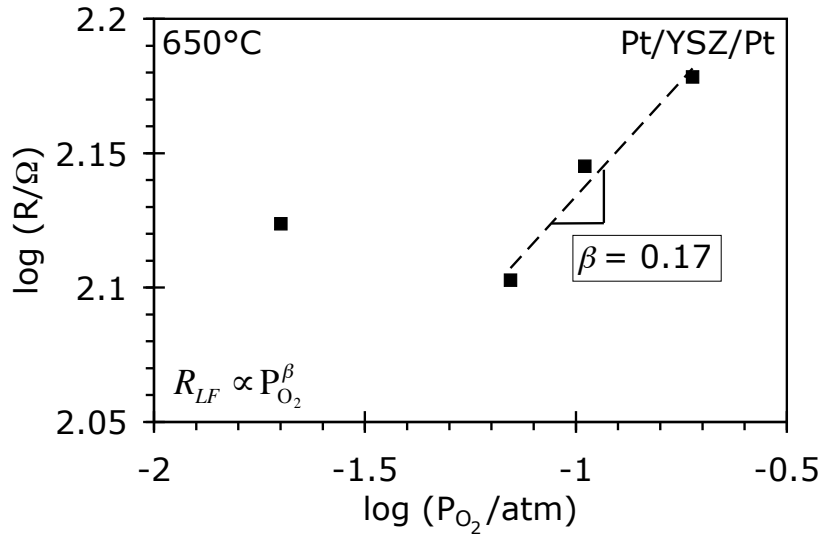

(b)

Figure 6: 


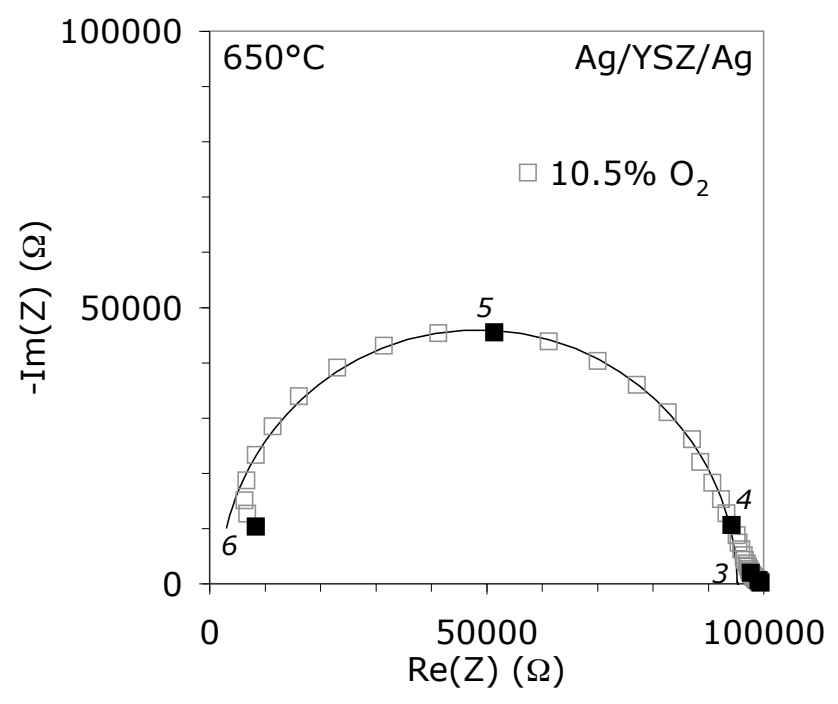

Figure 7: 


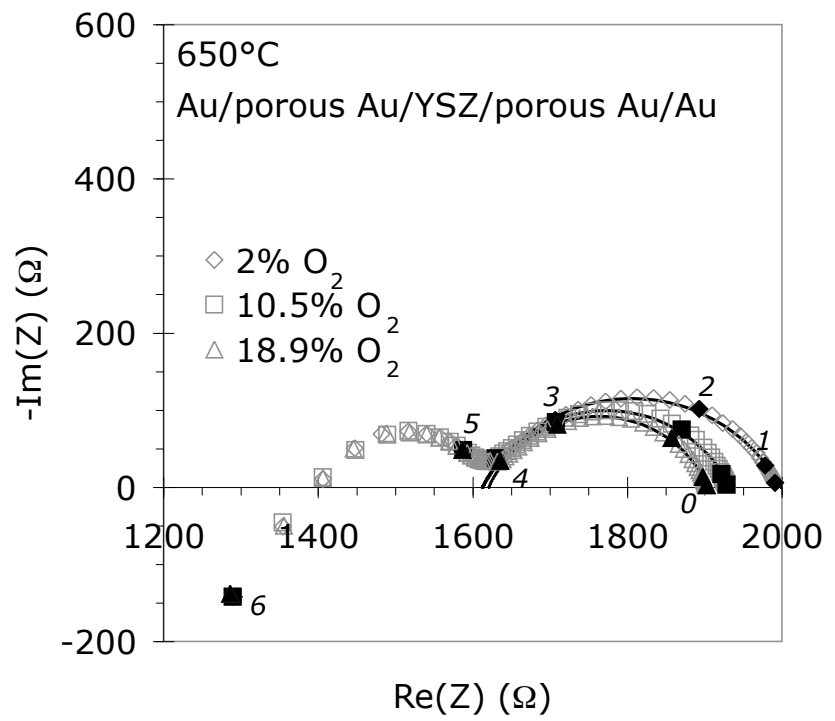

(a)

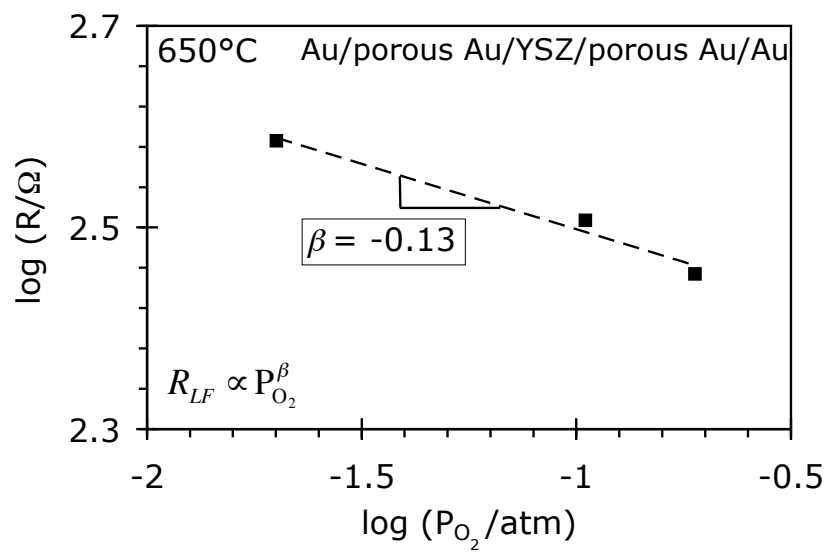

(b)

Figure 8: 


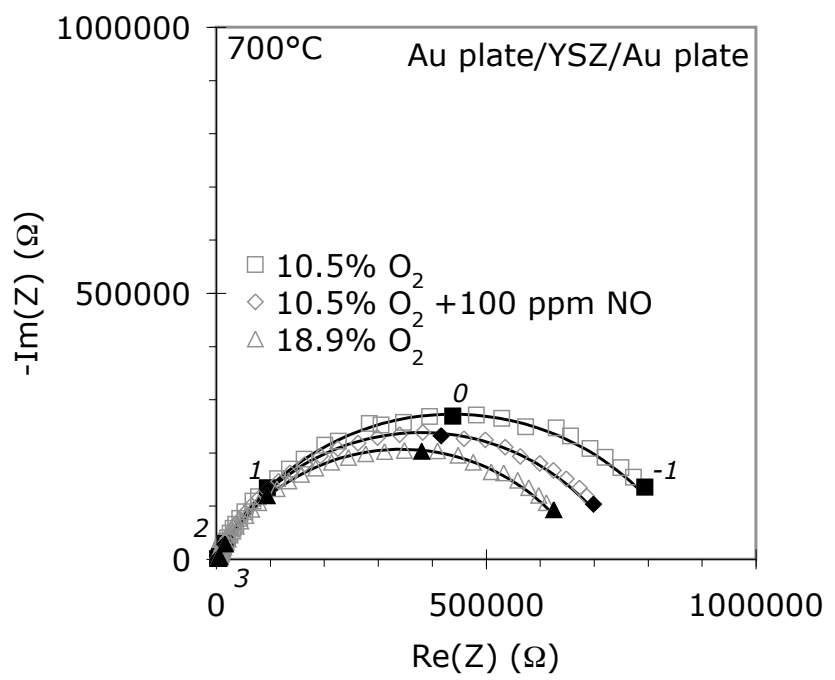

Figure 9: 


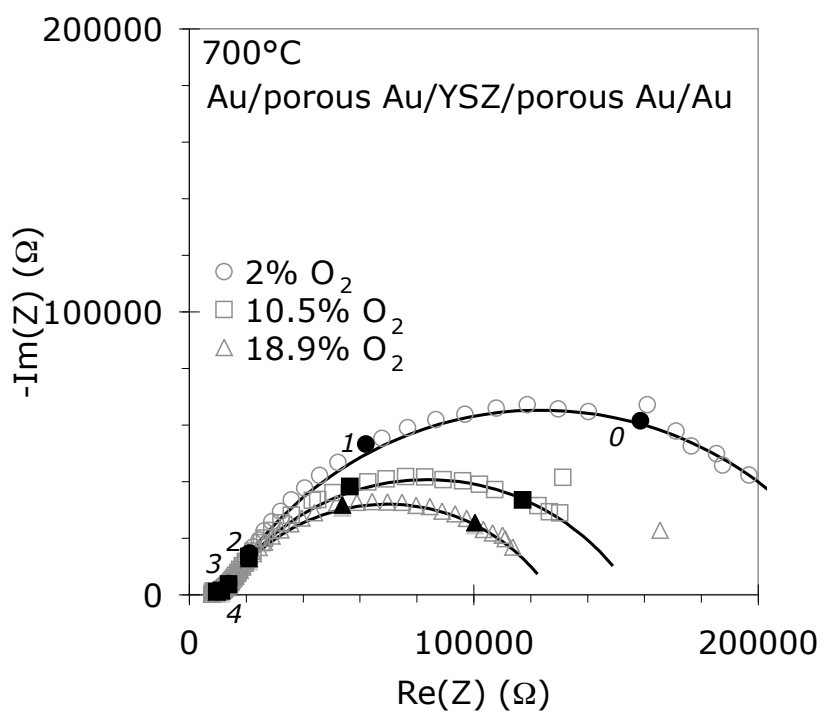

(a)

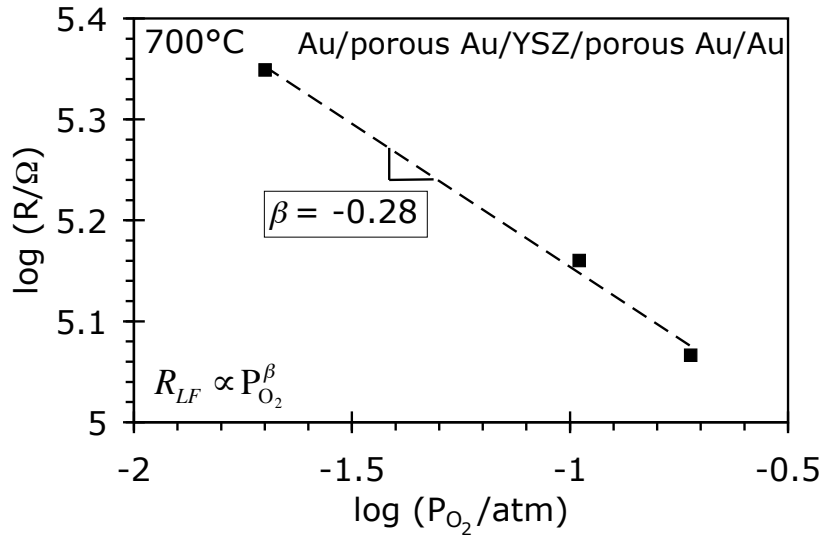

(b)

Figure 10: 